\title{
A review of the total syntheses of triptolide
}

\author{
Xiang Zhang ${ }^{* 1}$, Zaozao Xiao ${ }^{* 2}$ and Hongtao $\mathrm{Xu}^{* 3}$
}

\author{
Review \\ Address: \\ ${ }^{1}$ Department of Pharmacy, the First Affiliated Hospital of Zhengzhou \\ University, Zhengzhou 450052, China, ${ }^{2}$ College of Chemical \\ Engineering and Materials Science, Tianjin University of Science \& \\ Technology, Tianjin 300457, China and ${ }^{3}$ Shanghai Institute for \\ Advanced Immunochemical Studies (SIAIS), ShanghaiTech \\ University, Shanghai, 201210, China \\ Email: \\ Xiang Zhang* - x8long@163.com; Zaozao Xiao* - \\ zaozao_xiao@yeah.net; Hongtao Xu* - xuht@shanghaitech.edu.cn \\ * Corresponding author \\ Keywords: \\ total synthesis; Tripterygium wilfordii Hook F; triptolide
}

Beilstein J. Org. Chem. 2019, 15, 1984-1995.
doi:10.3762/bjoc.15.194

Received: 06 April 2019

Accepted: 03 August 2019

Published: 22 August 2019

Associate Editor: S. Bräse

(C) 2019 Zhang et al.; licensee Beilstein-Institut. License and terms: see end of document.

\begin{abstract}
Triptolide is a complex triepoxide diterpene natural product that has attracted considerable interest in the organic chemistry and medicinal chemistry societies due to its intriguing structural features and multiple promising biological activities. In this review, progress in the total syntheses of triptolide are systematically summarized. We hope to gain a better understanding of the field and provide constructive suggestions for future studies of triptolide.
\end{abstract}

\section{Introduction}

Triptolide (1, Figure 1) is the first diterpenoid triepoxide isolated from Tripterygium wilfordii Hook F. (TWHF) in 1972 [1]. It has attracted an ever-increasing attention due to its intriguing structural features and various promising pharmacological activities [2-4], such as antiproliferative, antifertility [5], anti-osteoporosis [6], immunosuppressive and anti-inflammatory activities [7]. Reports have indicated that triptolide induces apoptosis, triggers autophagy [8], and arrests cell cycle progression through modulating the relevant signaling pathways involved in the regulation of reactive oxygen species (ROS) and/or nitric oxide (NO) [9], histone methyltransferase [10], HSP70 [11] Jak2, Bcl-2/Bax [12], caspase 8 [13], NF-кB [14], X-linked inhibitor of apoptosis protein (XIAP) [15], MAPK, PI3K [16] and MPK1, ERK-1/2, and JNK-1/2 [17]. The cross-talk network amongst these targets and signaling pathways are considered to be responsible for the multiple anticancer activities of triptolide [18-24]. Triptolide could also suppress inflammation and stimulate cytoprotection by regulating pro-inflammatory cytokines and chemokines such as IFN- $\gamma$ [25], RANTES [26], IL-8 [27], COX-2 and NO [28]. These may associate with its effect on inflammatory relating diseases such as Parkinson's disease [28], and kidney disease [29,30]. Meanwhile, through regulating immune-related cells, triptolide also showed great potential for the treatment of rheumatoid arthritis (RA) [31], systemic lupus erythematosus (SLE) and skin allograft rejection [32].

Despite the promising biological activities of triptolide, the narrow therapeutic window and multi-organ toxicity hindered 


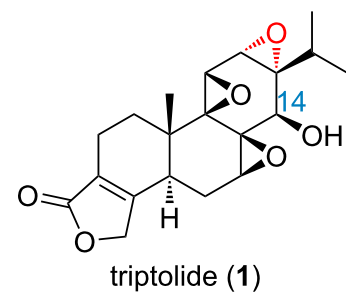

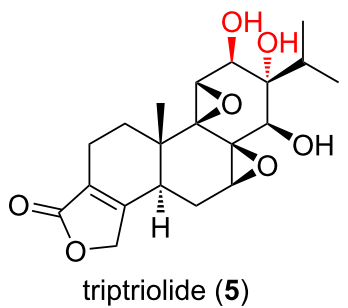

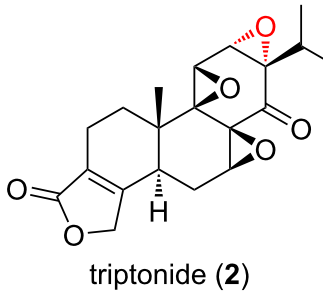

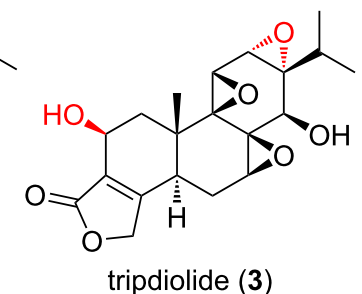

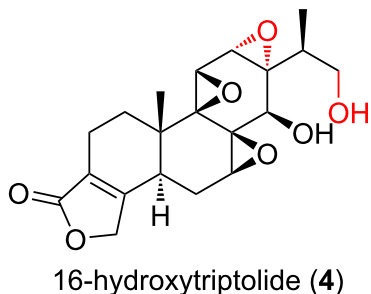

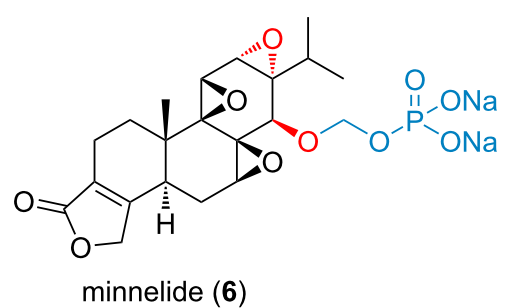

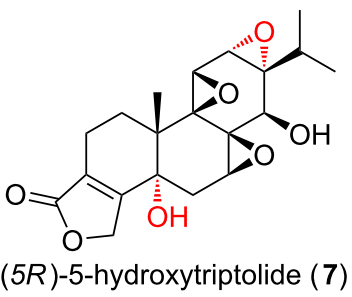

Figure 1: Structures of triptolide (1), triptonide (2), tripdiolide (3), 16-hydroxytriptolide (4), triptriolide (5), minnelide (6) and LLDT-8 (7).

greatly its clinical progress. Reports have shown that triptolide could cause reproductive toxicity [33], nephrotoxicity [34], hepatotoxicity [35], myocardial damage [36] and gastrointestinal tract symptoms [37]. In order to overcome the above issues and find derivatives with good drug-like properties, extensive total syntheses and structure modifications have been executed in the past two decades [38-51]. With the increasingly clear structure-activity relationships (SARs) [52-61], some derivatives of triptolide, such as minnelide 6 and (5R)-5-hydroxytriptolide (LLDT-8, 7) have progressed into clinic for the treatment of pancreatic cancer and rheumatoid arthritis (RA) [61,62], respectively.

In order to gain a comprehensive and deep understanding of the area and provide suggestions for triptolide's future studies, the recent progress of the total syntheses was systematically reviewed in this article. Syntheses were clustered based on: i) syntheses using tetralone (Figure 2, route A nad B), L-abietic acid and/or L-dehydroabietic acid as starting materials (route $\mathrm{C}$, $\mathrm{D}$ and $\mathrm{E})$; ii) syntheses using Diels-Alder reactions for the construction the A, B and C-rings (route $\mathrm{F}$ and $\mathrm{G}$ ); iii) syntheses using polyene cyclization to construct the core structure (route $\mathrm{H}, \mathrm{I}, \mathrm{J}, \mathrm{K}$, and L); iv) syntheses highlight the utilization of metal-catalyzed reactions ( $\mathrm{M}$ and $\mathrm{N}$ ).

\section{Review}

The intriguing structural features of triptolide and its relatives have provided a rich playing field for the design and development of total synthesis strategies. Structurally, it has nine chiral centers, three successive epoxides and a butenolide. Since the pioneering works of Berchtold, Tahara and their co-workers [45,63-65], several racemic and/or asymmetric total syntheses of triptolide and its relatives have been carried out in many research groups.

The first racemic total synthesis of triptolide was reported 1980 by Berchtold and co-workers (Figure 2, route A, and Scheme 1) [66]. The key steps include: i) construction of the A-ring by aldol condensation, ii) construction of the butenolide (D-ring) by acid-catalyzed lactonization, and iii) construction of the epoxides by a newly developed methodology. The synthesis commenced from the alkylation of tetralone 22 with 3-(2iodoethyl)dihydrofuran-2(3H)-one (23) to give diastereomeric lactones that subsequently reacted with dimethylamine to afford a 1:1 mixture of diastereomeric amides 39. Collins oxidation of 39 gave an aldehyde intermediate, which subsequently subjected to an aldol condensation using a ten-fold weight excess of neutral alumina quantitatively provided $\mathbf{4 0}$ and $\mathbf{4 1}$ in a smallscale reaction. The yield varied in large-scale reactions mainly due to the difficulty in extraction of $\mathbf{4 0}$ and $\mathbf{4 1}$ from the large quantity of alumina. Dehydration of the mixture of $\mathbf{4 0}$ and $\mathbf{4 1}$ in benzene quantitatively afforded a 1:2 mixture of $\mathbf{4 2}$ and its C-3 epimer 41. Reduction of the epimers with sodium borohydride and subsequent treatment with hydrochloric acid $(2 \mathrm{~N})$ gave single isomer $\mathbf{4 3}$. Treatment of $\mathbf{4 3}$ with methoxide ions in methanol at room temperature for 15 min gave the desired C-5 transbutenolide 8 (40\%) along with its C-5 cis-epimer 44 (60\%), which is the sole product from the base-catalyzed isomerization of 43. Epoxidation of $\mathbf{4 3}$ gave a $\mathrm{C}-4,5$-epoxide intermediate, which was isomerized in the presence of base and dehydrated to give diene $\mathbf{4 5}$. Reduction of $\mathbf{4 5}$ with $10 \% \mathrm{Pd} / \mathrm{C}$ afforded $\mathbf{8}$ in good yield $(60 \%)$ after recrystallization. Benzylic oxidation of $\mathbf{8}$ $\left(\mathrm{CrO}_{3} / \mathrm{HOAc}, 45 \%\right)$, followed by $\mathrm{C}-14$ ether cleavage $\left(\mathrm{BBr}_{3}\right)$ and subsequent sodium borohydride reduction afforded 46 with 


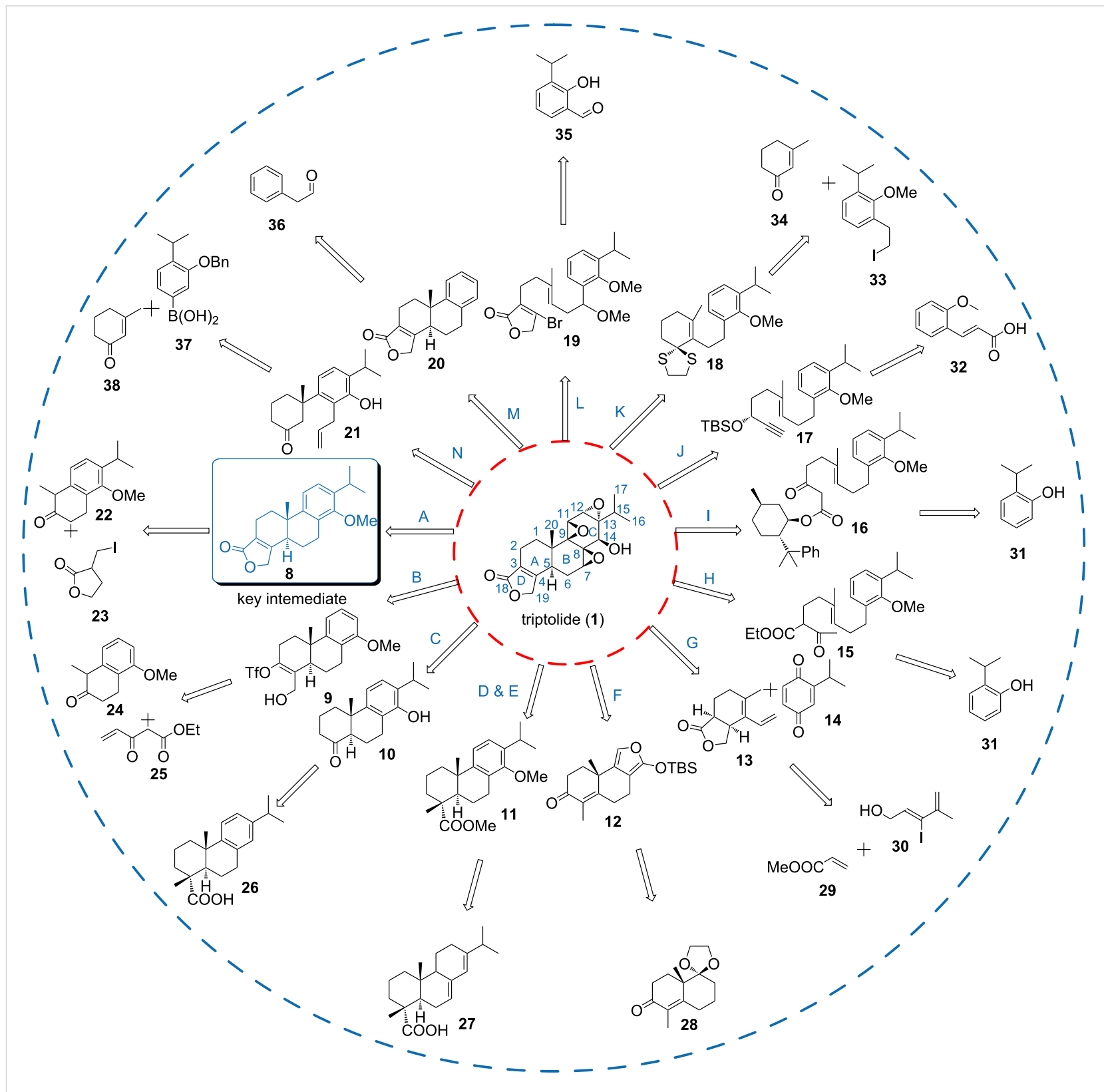

Figure 2: Syntheses of triptolide.

the desired stereochemistry of the $\mathrm{C}-7$ benzylic hydroxy group. Compound $\mathbf{4 6}$ was converted to triptonide $\mathbf{2}$ by Alder periodate reaction $\left(\mathrm{NaIO}_{4}, 74 \%\right.$ ), and a sequencing $m$-CPBA epoxidation and basic hydrogen peroxide oxidation $\left(\mathrm{H}_{2} \mathrm{O}_{2} / \mathrm{OH}^{-}\right)$procedure (two steps, 28\%). Finally, sodium borohydride reduction of 2 afforded triptolide $(\mathbf{1}, 21 \%)$ and 14-epitriptolide (48, 68\%). Overall, the first total synthesis of racemic triptolide was finished from tetralone 22 in 16 steps. Although the intractable problems in some transformations, such as the neutral aluminamediated aldol condensation to produce $\mathbf{4 0}$ and $\mathbf{4 1}$, the isomerization of olefin $\mathbf{4 3}$, the benzylic oxidation of $\mathbf{8}$, the use of $m$-CPBA to introduce the C-9,11 epoxide and the non-stereose- lective reduction of the $\mathrm{C}-14$ carbonyl group using sodium borohydride, caused an unacceptable overall yield (1.6\%). This pioneering work undoubtedly established the basis for the future syntheses of triptolide.

In 2014, Li and co-workers further reported a formal asymmetric synthesis of triptolide from tetralone $\mathbf{2 4}$ (Figure 2, route $B$ and Scheme 2) [50], featuring a Robinson annulation of Nazarov's reagent 25 with 5-methoxy-2-tetralone $\mathbf{2 4}$ in the presence of enantiomerically pure $(R)$ - $\alpha$-phenylethylamine (49) to generate key tricyclic intermediates $\mathbf{5 1}$ and 52, a Pd(II)-catalyzed carbonylation-lactonization reaction of $\mathbf{9}$ to construct the 


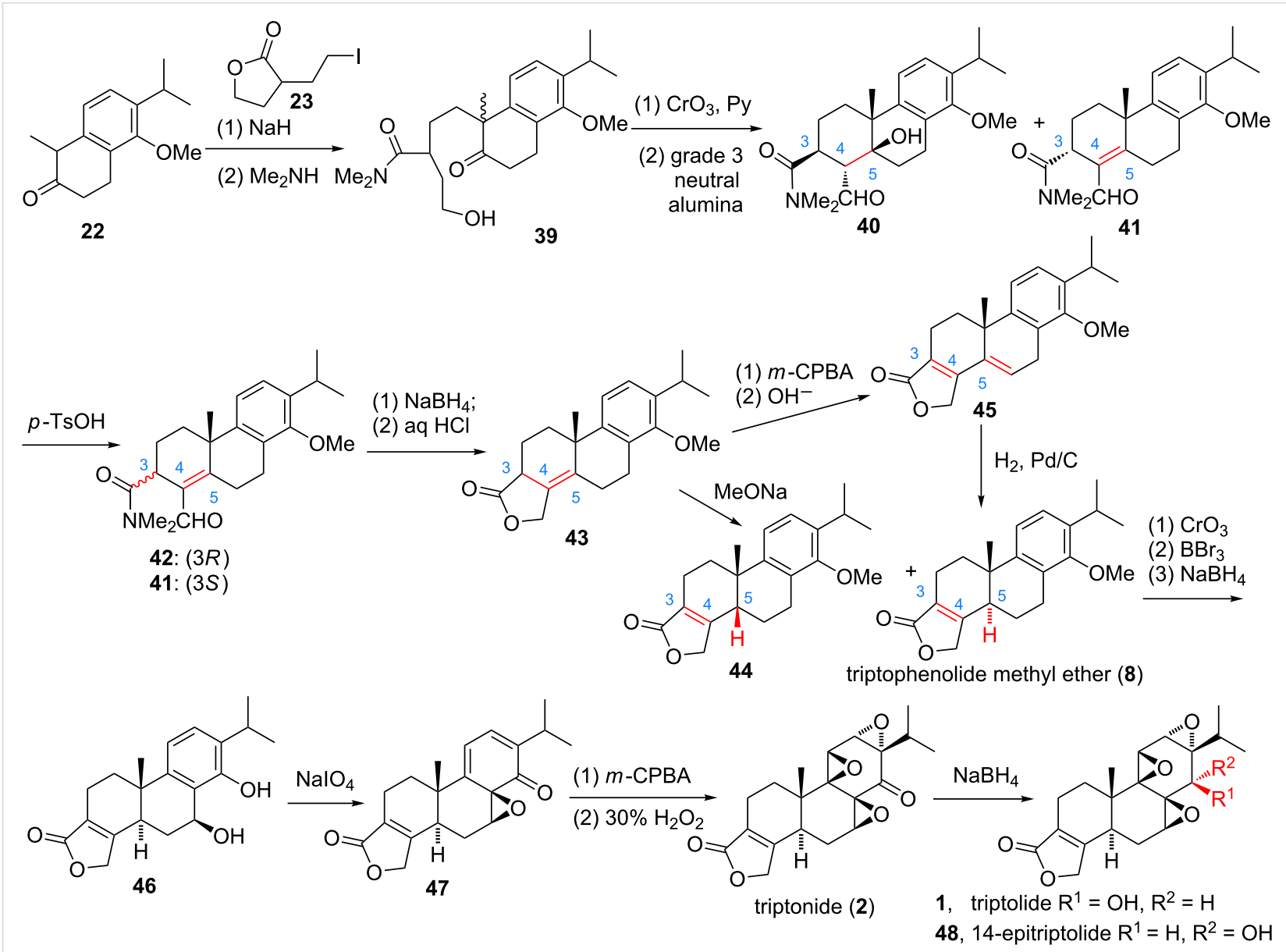

Scheme 1: Berchtold's synthesis of triptolide.

butenolide (D-ring), and a Friedel-Crafts isopropylation to install the C-13 isopropyl group. Still, the construction of the $\mathrm{C}-5$ trans junction A-/B-ring was problematic, direct reduction of 51 and 52 with either $\mathrm{Pd} / \mathrm{BaSO}_{4} / \mathrm{H}_{2}$ or $\mathrm{Li} / \mathrm{NH}_{3} / t-\mathrm{BuOH}$ could not give the desired ketoester $\mathbf{5 4}$ in satisfactory yield for a target-oriented synthesis. Fortunately, after trying many conditions and procedures, a three-step indirect approach that include silyl ether formation of the mixture of $\mathbf{5 1}$ and $\mathbf{5 2}$, subsequent Pd/C-catalyzed hydrogenation and tetrabutylammonium fluoride (TBAF)-mediated desilylation yielding the desired tricyclic 54 ( $83 \%$ yield, 98\% ee). Overall, the known intermediate 7-oxotriptophenlide $\mathbf{5 9}$ was obtained in an efficient, elegant and scalable way in 10 steps with $18.5 \%$ overall yield. Importantly, by late-stage installation of the C-13 isopropyl group, this synthesis also provided a useful approach for the synthesis of other structurally relevant derivatives of triptolide such as C-15 and C-16 modified derivatives of triptolide.

In 1980, van Tamelen and co-workers reported an asymmetric synthesis of triptolide using readily available L-dehydroabietic acid (26) as starting material (Figure 2, route C and Scheme 3)
[67]. In this synthesis, the key step was the construction of the butenolide (D-ring). L-Dehydroabietic acid was converted to C-14 trifluoroacetate $\mathbf{6 0}$ by a known electrophilic substitution procedure that was developed by Tahara and co-workers [64]. Curtius rearrangement of $\mathbf{6 0}$ gave an isocyanate intermediate, which was reduced with $\mathrm{LiAlH}_{4}$ followed by reductive amination affording tertiary amine intermediate 61. Oxidation of 61 to its corresponding $\mathrm{N}$-oxide followed by Cope elimination gave olefin 62. Cleavage of olefin $\mathbf{6 2}$ with $\mathrm{OsO}_{4}$ and $\mathrm{NaIO}_{4}$ afforded ketone intermediate 10, which was enolized by $(\mathrm{iPr})_{2} \mathrm{NLi}$ (LDA) and further reacted with formaldehyde to afford hydroxy ketone 63. Protection of the hydroxy group of $\mathbf{6 3}$ as 2-methoxypropyl ether, followed by successive treatment with $\mathrm{PhCH}_{2} \mathrm{OCH}_{2} \mathrm{Li}$ and $\mathrm{HCl}-\mathrm{THF}$ ( $\mathrm{pH}$ 1) gave triolmonobenzyl ether 64. Protection of the phenolic hydroxy group to its corresponding monoacetate followed by oxidation of the primary hydroxy group and dehydration yielded $\alpha, \beta$-unsaturated aldehyde $\mathbf{6 5}$. Oxidation of $\mathbf{6 5}$ to the corresponding carboxylic acid followed by hydrogenolysis with $\mathrm{H}_{2} / \mathrm{Pd}-\mathrm{C}$ led in spontaneous lactonization to give the key butenolide 66. Oxidation of $\mathbf{6 6}$ with $\mathrm{CrO}_{3} / \mathrm{AcOH}-\mathrm{H}_{2} \mathrm{O}$, followed by saponification and reduc- 


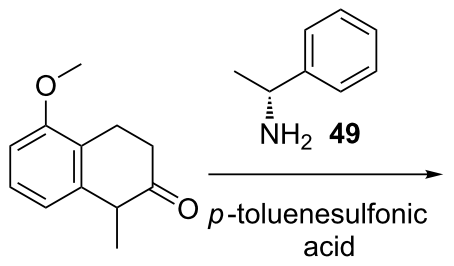

24<smiles>COc1cccc2c1CCC(N[C@H](C)c1ccccc1)=C2C</smiles>

50<smiles>C=CC(=O)CC(=O)OCC</smiles>

$$
25
$$

(1) $40^{\circ} \mathrm{C}$

(2) $\mathrm{AcOH} / \mathrm{H}_{2} \mathrm{O}$

(3) $\mathrm{KOH}$

(4) $\mathrm{HCl}$<smiles></smiles>

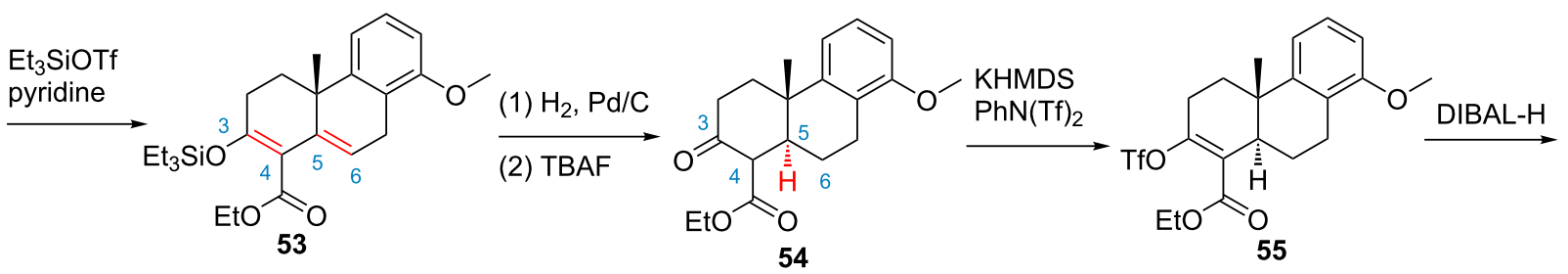

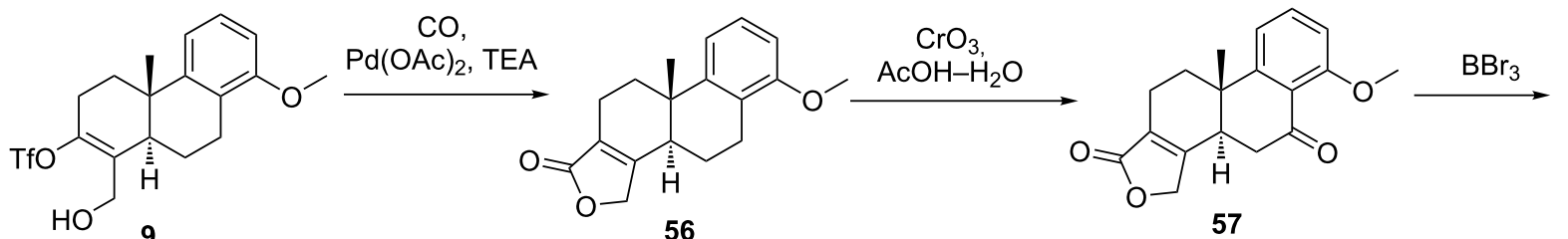

9

56

57<smiles>CC12CCC3=C(COC3=O)[C@@H]1CC(=O)c1c(O)cccc12</smiles><smiles>CC(C)c1ccc2c(c1O)C(=O)C[C@H]1C3=C(CC[C@]21C)C(=O)OC3</smiles><smiles>C#CCCCCC</smiles>

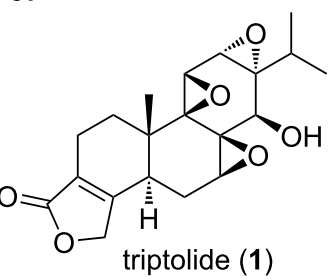

Scheme 2: Li's formal synthesis of triptolide.

tion afforded known benzyl alcohol 46 (19\% from 66). Then, phenol 46 was converted to the corresponding epoxydienone via the methodology developed by Alder et al., which was treated without purification with basic $\mathrm{H}_{2} \mathrm{O}_{2}$ to yield diepoxide 67, along with its $12,13-\beta$-isomer. The mixture was immediately oxidized with $3,5-\left(\mathrm{NO}_{2}\right)_{2} \mathrm{C}_{6} \mathrm{H}_{3} \mathrm{CO}_{3} \mathrm{H}$ and $\mathrm{Na}_{2} \mathrm{HPO}_{4}$ to give triptonide (2,15\% from 67$)$, and reduction of triptonide via the reported procedure finalized the synthesis of triptolide. Overall, the first asymmetric total synthesis of (-)-triptonide (19 steps, 0.06\% yield) and formal synthesis of triptolide were realized from L-dehydroabietic acid (26). Although the overall yield of the synthesis is very low, the authors can ensure the optical purity of tripolide by utilizing the natural building block L-dehydroabietic acid, and therefore could give a lot of inspiration for the future syntheses of triptolide and other related natural products from resource-abundant natural scaffolds.

Alternatively, inspired by the use of a natural diterpene scaffold as starting material for the synthesis of triptolide by van Tamelen and Tahara, Alvarez-Manzaneda's group and Li's group, respectively, reported formal syntheses of triptolide from
L-abietic acid (27, Figure 2, route D and E) [68,69]. In both syntheses, the key steps include the regioselective dihydroxylation and etherification to introduce the C-14 hydroxy group and the construction of the butenolide moiety. Particularly, the characteristics of Li's route are low cost, high yield (9 steps, $44 \%$ yield) and easy handling (all intermediates could be scaled up to 100 grams without losing of yield) for the synthesis of key intermediate $\mathbf{8}$.

In order to further improve the synthesis of the key intermediate triptophenolide methyl ether (8), van Tamelen and co-workers further developed a synthesis as shown in Scheme 4 (Figure 2, route F) [70]. This synthesis features two new methodologies of butenolide formation. The first butenolide formation started with the reaction of ketone $\mathbf{6 8}$ with carbon disulfide $\left(\mathrm{CS}_{2}\right)$ and iodomethane (MeI) to give the ketene dithioacetal intermediate 69, which was subjected to a Corey-Chaykovsky epoxidation, followed by acid hydrolysis to give butenolide $\mathbf{7 0}$. The second one is the reaction of alicyclic alcohol 73 with dimethylformamide dimethylacetal to give an allylic amide by means of a [2,3]-sigmatropic rearrangement of a carbene inter- 


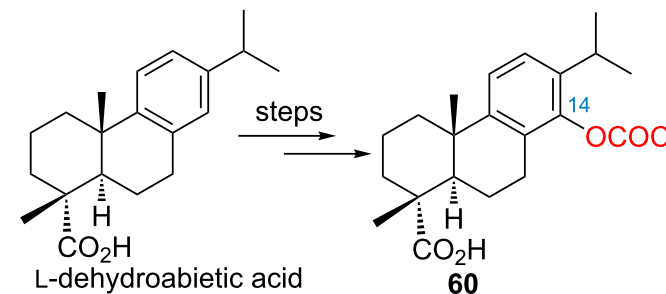

(26)<smiles>CC(C)c1ccc2c(c1O)CC[C@H]1C(=O)C[C@H](C(=O)O)CC[C@@]21C(=O)O</smiles><smiles>CC(C)c1ccc2c(c1O)CCC1C(=O)[C@@H](CO)CCC21C</smiles>

63

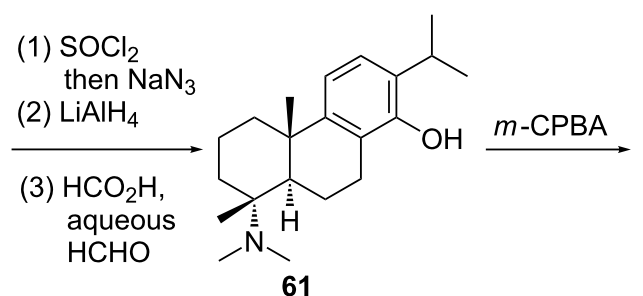

61<smiles>C=C1CCCC2(C)Cc3ccc(C(C)C)c(O)c3CCC12</smiles>

62

(1) $\mathrm{MeOC}\left(\mathrm{CH}_{3}\right)=\mathrm{CH}_{2}-\mathrm{AcOH}$

(2) $\mathrm{PhCH}_{2} \mathrm{OCH}_{2} \mathrm{Li}$ $\mathrm{HCl}-\mathrm{THF}(\mathrm{pH}$ 1)<smiles>CC(C)c1ccc2c(c1O)CCC1(C)C(COc3ccccc3)CCC(C)C21COc1ccccc1</smiles>

64

(1) $\mathrm{MeOC}\left(\mathrm{CH}_{3}\right)=\mathrm{CH}_{2}-\mathrm{AcOH}$, $\mathrm{Ac}_{2} \mathrm{O}$, pyridine; then $\mathrm{HCl}-\mathrm{MeOH}(\mathrm{pH} 1)$

(2) $\mathrm{CrO}_{3}$-pyridine $\cdot \mathrm{HCl}$

(3) $\mathrm{o}-\mathrm{C}_{6} \mathrm{H}_{4}\left(\mathrm{NH}_{2}\right)_{2}-\mathrm{PhCO}_{2} \mathrm{H}$<smiles>C=CCCC1(C)c2ccc(C(C)C)c(OC(C)=O)c2CCC1OCC</smiles>

65

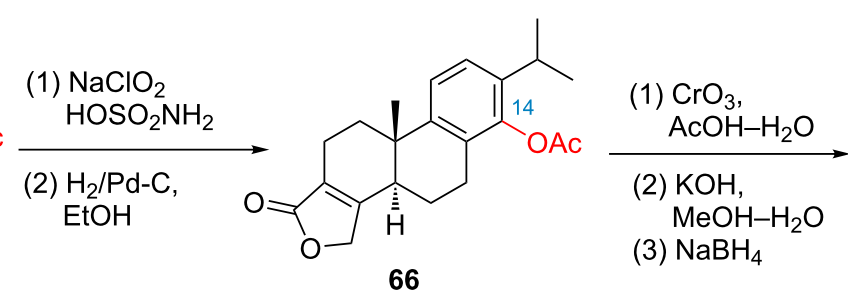

66<smiles>CC(C)c1ccc2c(c1O)C(O)CC1C3=C(CCC21C)C(=O)OC3</smiles>

Scheme 3: van Tamelen's asymmetric synthesis of triptonide and triptolide.<smiles>CCCC1=C2CCCC3(OCCO3)C2(C)CCC1=O</smiles>
(1) $\mathrm{Li} / \mathrm{NH}_{3}$
(2) $(\mathrm{EtO})_{2} \mathrm{POCl}$
$\stackrel{\text { (3) } \mathrm{Li} / \mathrm{EtNH}_{2}}{\text { (4) } \mathrm{H}_{2} \mathrm{SO}_{4}}$<smiles>CC1=CCCC2(C)C(=O)CCC[C@H]12</smiles>

68
(1) $\mathrm{CS}_{2}$, lithium 4-methyl-2,6-di-tertbutylphenoxide (2) Mel $\frac{\text { (1) } \mathrm{CH}_{2}=\mathrm{CHCO}_{2} \mathrm{CH}_{3}}{\text { (2) } \mathrm{HCl}-\mathrm{MeOH}}$

12<smiles>CCCOc1occ2c1CC[C@@H]1C(C)=CCC[C@@]21C</smiles><smiles>COc1c(C(C)C)ccc2c1CC[C@H]1C(CO)=CC[C@H](CO)[C@]21C</smiles>

(1) $\mathrm{HC}(\mathrm{OMe})_{2} \mathrm{NMe}_{2}$

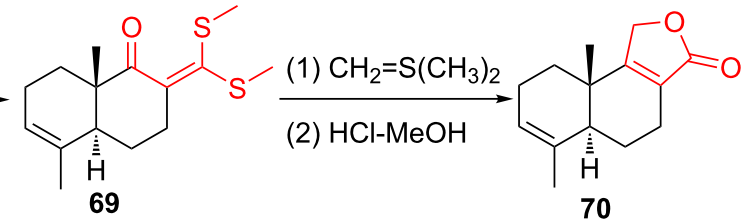<smiles>COC(=O)c1ccc2c(c1O)CC[C@H]1C(C)=CCCC21C</smiles>

71
(1) $\mathrm{Mel} / \mathrm{NaH}$ (2) $\mathrm{Li}$

(3) $\mathrm{CH}_{3} \mathrm{SO}_{2} \mathrm{Cl}$

(4) $\mathrm{Li} / \mathrm{NH}_{3}$<smiles>COc1c(C(C)C)ccc2c1CC[C@H]1C(C)=CCC[C@]21C</smiles>

72

(2) $m$-CPBA

74 
mediate. Epoxidation the allylic amide with $m$-CPBA gave 74, followed by lithium hexamethyldisilazide-induced $\beta$-elimination and acid hydrolysis to give the key triptophenolide methyl ether $(\mathbf{8})$ in racemic form (16.5\%).

In 2008, Sherburn and co-workers developed an approach to the formal synthesis of triptolide (Figure 2, route G, Scheme 5) [71]. Key features of the synthesis include two intermolecular Diels-Alder reactions and a newly developed deoxygenative aromatization procedure. The first enantioselective Diels-Alder reaction, which is an intermolecular cycloaddition and lactonization between (Z)-3-iodo-4-methylpenta-2,4-dien-1-ol (29) and methyl acrylate (30) in the presence of Mikami's (binol) $\mathrm{TiCl}_{2}$ catalyst to form the A- and D-ring. The second one involves the reaction of the bicyclic intermediate $\mathbf{1 3}$ and 2-isopropyl-1,4-benzoquinone (14) to form the B- and C-ring. Finally, a regio- and stereoselective reduction, methylation and dehydration procedure and a selenylation, oxidation and elimination procedure were employed to successfully achieve Berchtold's tetracyclic C-5,C-6 olefin intermediate $\mathbf{4 5}$ in only 7 steps with $8.1 \%$ overall yield in a protecting-group-free synthesis. However, we know the conversion of Berchtold's C-5,C-6 tetracyclic olefin intermediate $\mathbf{4 5}$ to triptophenolide methyl ether $(\mathbf{8})$ is a troublesome work $(60 \%$ yield) due to the formation of the thermodynamic more stable C-5 cis-epimer 44 [66]. Thus, it may not be possible to obtain the desired triptophenolide methyl ether $(\mathbf{8})$ in a satisfactory yield for a target-oriented synthesis.
As the key structure element of various di- and triterpenes, the trans-decalin scaffold is the ideal objective of numerous methodology studies. Inspired by nature's highly efficient and stereochemically controlled syntheses of terpenes, up to now, various synthetic strategies to trans-decalin have been developed, e.g., Brønsted acid or Lewis acid-mediated cationic polyene cyclization, transition-metal- or photocatalyst-mediated radical polyene cyclization [72]. The key to such transformation is to install a proper initiator within the substrate such as an allylic alcohol, an acetal, an aziridine, an $\mathrm{N}$-acetal, a hydroxylactam, or a 1,3-dicarbonyl moiety.

van Tamelen and co-workers originally reported a natureinspired acid-induced cationic polyene cyclization to construct the key trans-decalin scaffold (A- and B-ring) of triptolide (Figure 2, Scheme 6 and route H) [73]. In their synthesis, 2-isopropylphenol (31) was used as starting material to construct the key cyclization precursor ketoester $\mathbf{1 5}$, which was cyclized in the presence of $\mathrm{SnCl}_{4}$ to give tricyclic intermediate $\mathbf{8 3}$, followed by steps of functional group modification to install the butenolide (D-ring), and to finish the racemic synthesis of the key intermediate triptophenolide methyl ether (8) in 12 steps with $15 \%$ yield. Interestingly, in this synthesis only four intermediates needed to be purified.

In 1999, Yang and co-workers reported an elegant chiral auxiliary-assisted, lanthanide triflate-catalyzed oxidative radical polycyclization of olefin-cation-based enantioselective synthe-
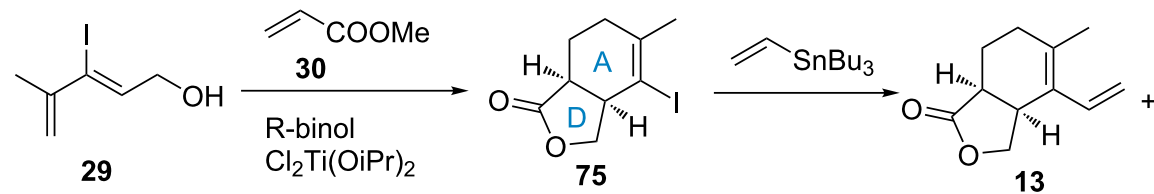<smiles>CC(C)C1=CC(=O)C=CC1=O</smiles>

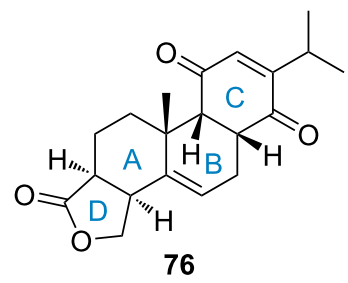

$\underset{\text { (2) } \mathrm{Ag}_{2} \mathrm{O}, \mathrm{Mel}}{\stackrel{\text { (1) } \mathrm{NaBH}_{4}}{\longrightarrow}}$

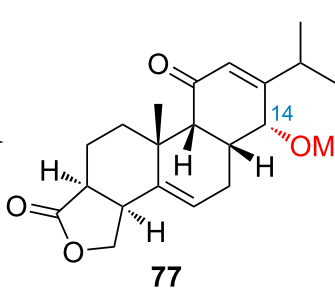<smiles>CC(C)(C)c1cc(C(C)(C)C)nc(C(C)(C)C)c1</smiles>
14

(1) $\mathrm{NE}_{3}$, TIPSOTf

(2) $\mathrm{PhSeCl}$

(3) $\mathrm{H}_{2} \mathrm{O}_{2}$<smiles>COc1c(C(C)C)ccc2c1CC=C1C3=C(CC[C@]12C)C(=O)OC3</smiles>

Berchtold's tetracyclic intermedaite 45 


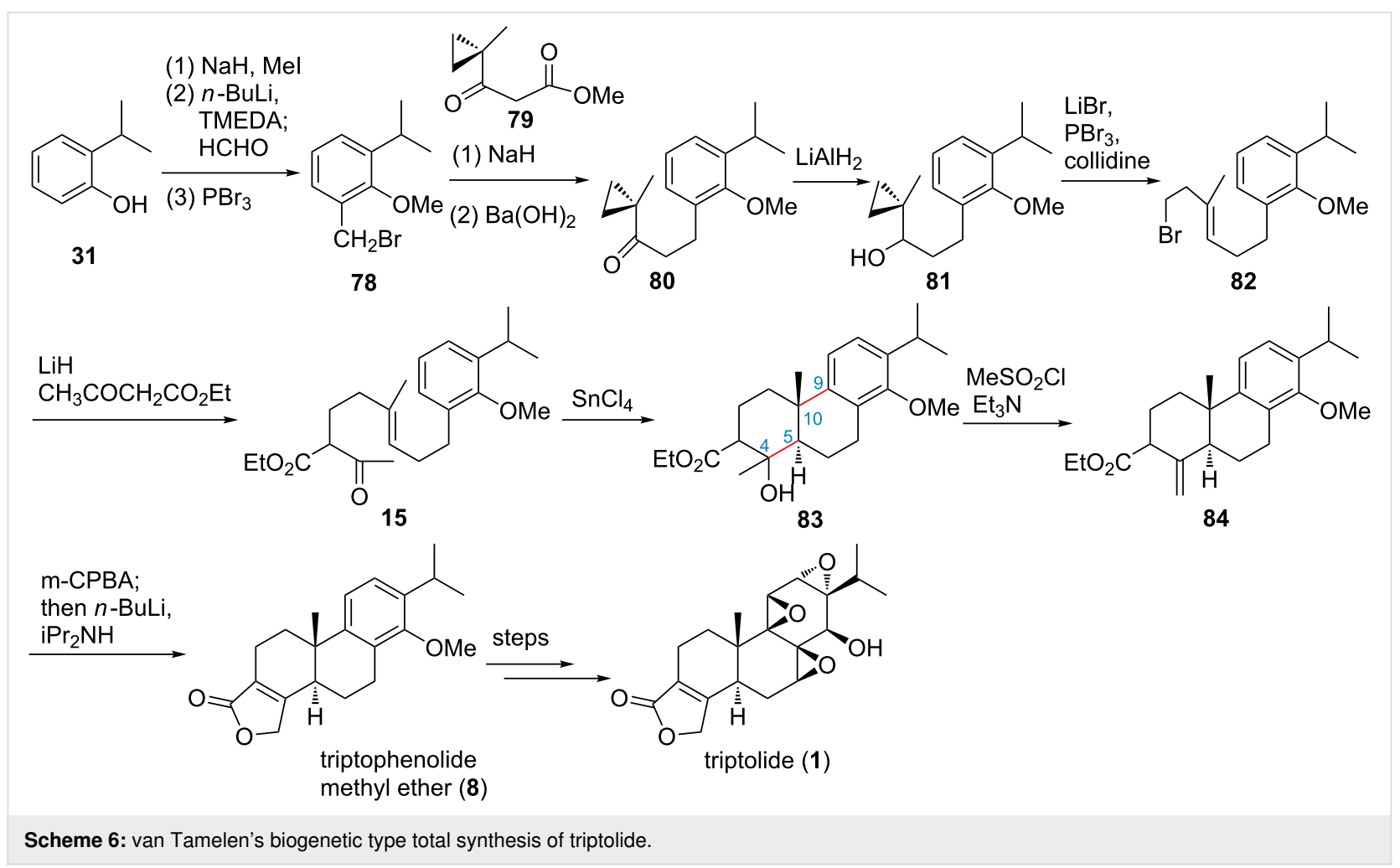

sis of triptolide (Figure 2, route I and Scheme 7) [74]. In this synthesis, commercially available 2 -isopropylphenol (31) was used as starting material, protection of $\mathbf{3 1}$ with chloromethyl methyl ether (MOM), followed by ortho lithiation and methylation with iodomethane, provided intermediate $\mathbf{8 5}$, which was lithiated and reacted with 3,3-dimethylallyl bromide, followed by changing the protecting group from MOM ether to methyl ether to provide olefin $\mathbf{8 6}$. Allylic oxidation of $\mathbf{8 6}$ followed by nucleophilic bromination of the resulting allylic alcohol gave bromide 87. Dianion displacement of the bromide of $\mathbf{8 7}$ gave ester 88. Ester exchange of $\mathbf{8 8}$ with (+)-8-phenylmenthol gave the key cyclization precursor 16. Oxidative radical cyclization of $\mathbf{1 6}$ in the presence of $\mathrm{Mn}(\mathrm{OAc})_{3}$ and $\mathrm{Yb}(\mathrm{OTf})_{3} \cdot \mathrm{H}_{2} \mathrm{O}$ afforded the major tricyclic diastereomer $\mathbf{8 9}(\mathrm{dr}=38: 1)$. Then the construction of the unsaturated lactone was performed by conversion of $\mathbf{8 9}$ to vinyl triflate $\mathbf{9 0}$, followed by reduction and palladium-catalyzed carbonylation-lactone formation to give key intermediate 8 [75-77]. After that, the three successive epoxides were installed by known procedures with some modification. The highlights were the introduction of the second epoxide as a single diastereomer via in situ-generated methyl(trifluoromethyl)dioxirane and the reduction of the $\mathrm{C}-14$ ketone in the presence of $\mathrm{Eu}(\mathrm{fod})_{3}$ to give triptolide (47\%) together with its C-14 $\alpha$-hydroxy epimer epi-triptolide (47\%).

In 2014, Li's group reported a divergent synthesis for triptolide and its relatives from commercially available acid 32 (Figure 2 , route $J$ and Scheme 8) [46]. This synthesis highlights the utilization of an indium(III)-catalyzed cationic polycyclization of $\mathbf{1 7}$ and a palladium-catalyzed carbonylation-in situ lactone formation to construct the key intermediate 94, which could readily be converted to triptolide and its relatives such as triptophenolid, tripdiolide, and 16-hydroxytriptolide via palladiumcatalyzed cross-coupling or Claisen rearrangement reactions. Importantly, by modification of the C-2,C3 olefin and late-stage installation of the C-13 isopropyl group, the synthesis also provides a new useful approach for the synthesis of other structurally relevant derivatives of triptolide.

In 2011, as their ongoing work that devoted to the synthesis of triptolide, Batti and co-workers developed a novel highly diastereoselective methodology that features 6-endo-trig cyclization of 2-alkenyl-1,3-dithiolanes to access trans-decalins (Figure 2, route K) [78]. Density functional theory calculation (DFT) studies indicated that the 2-alkenyl-1,3-dithiolane moiety acts as a latent initiator, which triggers the cationic 6-endo-trig cyclization in the presence of trimethylsilyl trifluoromethanesulfonate (TMSOTf) in a diastereoselective and stepwise manner. This novel methodology provides a shorter access to the intermediate 97, which is a key intermediate for the synthesis of triptolide.

Recently, photoredox catalysis has emerged as a powerful and high-yielding method for the generation of carbon radicals via 


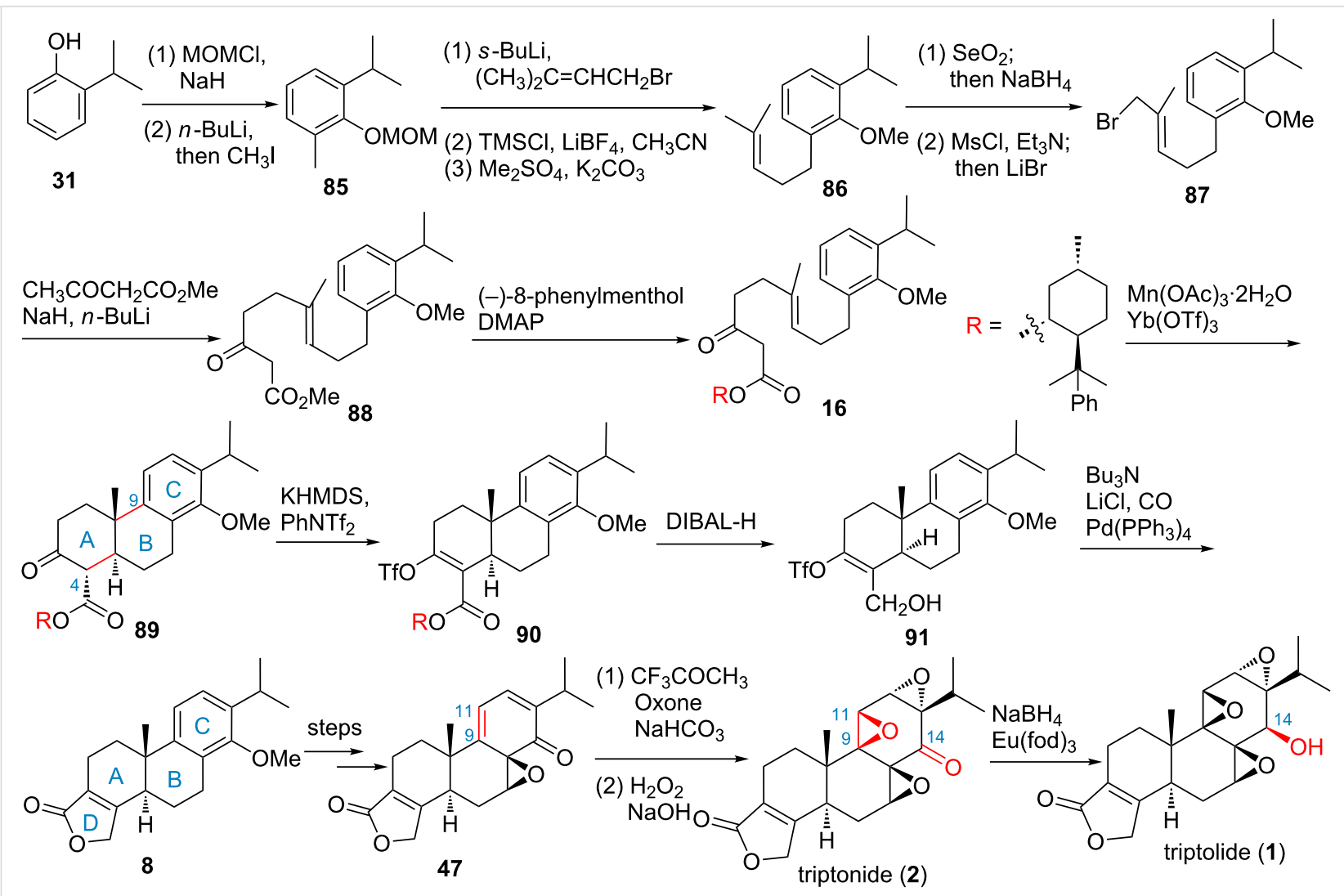

Scheme 7: Yang's total synthesis of triptolide.

single-electron transfer (SET). In 2016, Barriault and co-workers reported a methodology that features the utilization of dimeric gold complex $\left[\mathrm{Au}_{2}(\mathrm{dppm})_{2}\right] \mathrm{Cl}_{2}$ and ultraviolet $\mathrm{A}$ (UV, $365 \mathrm{~nm}$ ) light to direct arylation of bromide-substituted butenolides or cyclic enones [51]. Photoexcitation (UV, $365 \mathrm{~nm})$ of $[\mathrm{Au}-\mathrm{Au}]^{2+}$ generated $[\mathrm{Au}-\mathrm{Au}]^{2+*}$, which could then effectively reduce the vinyl $\mathrm{C}-\mathrm{Br}$ bond via a SET to generate the vinyl radical. This radical then cyclizes with an aryl group to generated a tricyclic intermediate bearing a tertiary radical. A simultaneous oxidation of the tertiary radical and reduction of the $[\mathrm{Au}-\mathrm{Au}]^{3+}$ ion could give the cyclization product and regenerate the dimeric gold photocatalyst. Later, the utility of this photoredox methodology was demonstrated in a concise formal synthesis of triptolide (1) via the reaction of bromobutenolide 19 under the optimal photoredox conditions to provide tetracyclic intermediate $19 \mathbf{i}(\mathrm{dr}=1: 1$, Scheme 8 , route $\mathrm{L})$, with a cis A-/B-ring connection rather than the desired trans connection. Treatment of 19i with $\mathrm{H}_{2} \mathrm{SO}_{4}$, followed by $\mathrm{RuCl}_{2}\left(\mathrm{PPh}_{3}\right)_{3}$-catalyzed double bond isomerization gave the known intermediate 45.

Thanks to the great advance of transition metal-mediated or catalyzed reactions that have been widely used for the construction of $\mathrm{C}-\mathrm{C}, \mathrm{C}-\mathrm{N}, \mathrm{C}-\mathrm{O}, \mathrm{C}-\mathrm{S}$, and $\mathrm{C}-\mathrm{X}(\mathrm{X}=\mathrm{F}, \mathrm{Cl}, \mathrm{Br}$ or $\mathrm{I})$ bonds in synthetic organic chemistry, and especially the transition metal-catalyzed functionalization of unreactive $\mathrm{C}-\mathrm{H}$ bonds, either $\mathrm{C}_{\mathrm{sp} 2}$ or $\mathrm{C}_{\mathrm{sp} 3}$, a revolution in the synthesis of complex natural products (NPs) has been evolved. It provides a powerful toolbox to access complex natural structures and has the potential to streamline the synthesis. In 2014, Li and co-workers reported a metal-mediated reactionbased formal synthesis of triptolide and triptonide (Figure 2, route M) [48]. This synthesis highlights the use of Noyori's ruthenium-catalyzed enantioselective transfer hydrogenation to introduce the chiral center; the indium(III)-catalyzed cationic polyene cyclization to construct the tricyclic A-, B- and C-ring system; palladium-catalyzed carbonylation and in situ lactone formation, and rhodium(II)-catalyzed double bond migration to construct the D-ring; and palladiumcatalyzed $\mathrm{C}_{\mathrm{sp} 2}-\mathrm{H}$ oxygenation to install the $\mathrm{C}-14$ hydroxy group. In 2016, Qin and co-workers developed a catalytic asymmetric route toward the formal synthesis of triptolide (Figure 2, route N) [43]. This synthesis highlighted the palladium-catalyzed asymmetric addition of arylboronic acid $\mathbf{3 7}$ to 3-methylcyclohex-2-en-1-one (38) to form the C-10 quaternary chiral center, and a subsequent Claisen rearrangement and an aldol reaction to furnish the trans-decalin A/B ring system. 


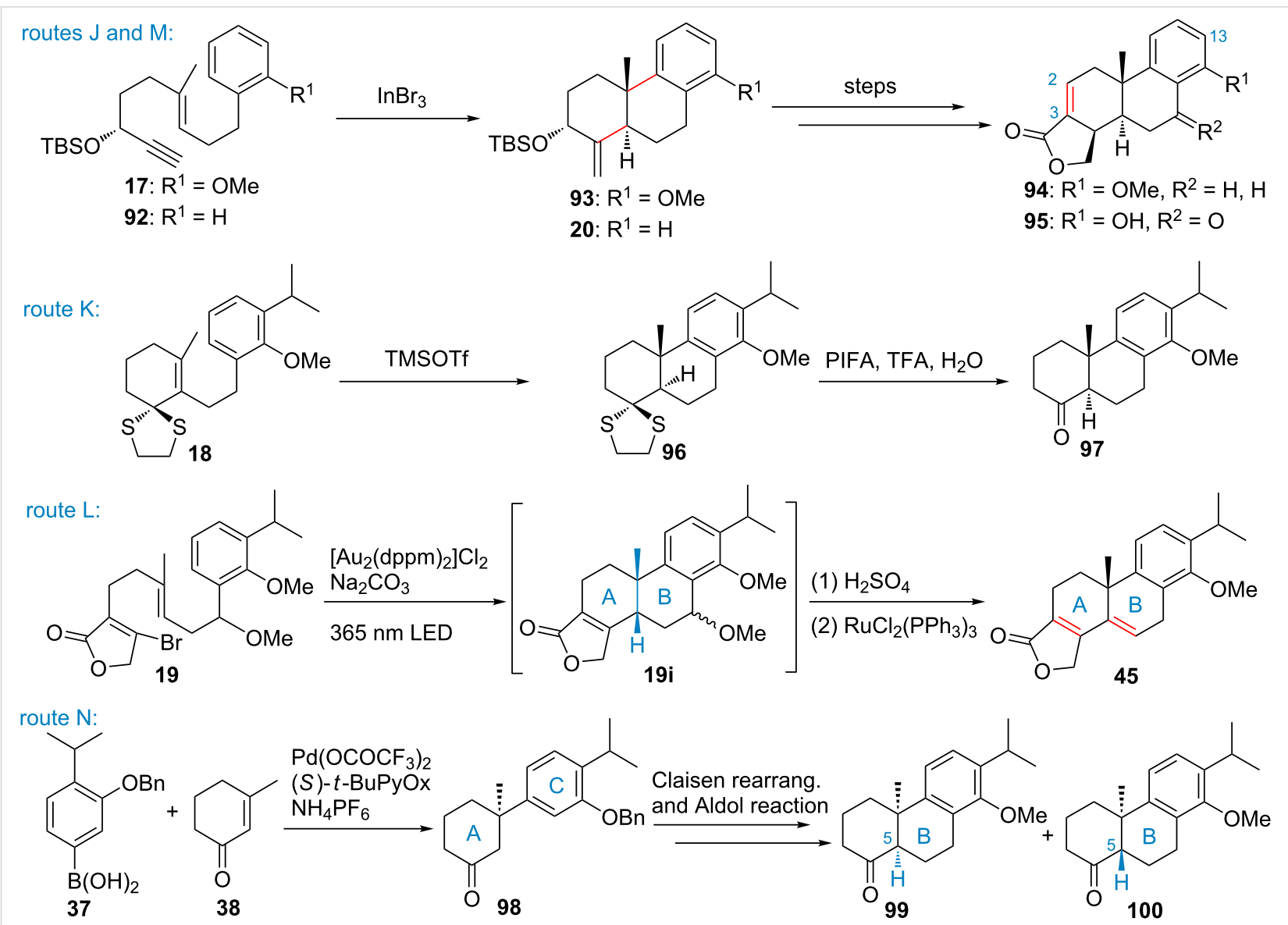

Scheme 8: Key intermediates or transformations of routes $\mathrm{J}-\mathrm{N}$.

\section{Conclusion and Future Perspectives}

Taken together, the intriguing structural features, the promising multiple biological activities and the lack of natural sources have made triptolide an attractive target for total synthesis. So far, lots of total syntheses and formal syntheses of triptolide and its relatives have been established since the pioneering works of Berchtold and Tahara. Each synthesis has its advantages and disadvantages, the key points in the synthesis of triptolide are: i) the construction of the trans-decalin A-/B-ring system; ii) the construction of the butenolide (D-ring) and iii) the installation of the three successive epoxides (C-ring). In future syntheses the following issues should be considered: i) avoiding the isomerization of the C-5 chiral center; ii) development of a new method for the $\beta$-selective reduction of the $\mathrm{C}$ - 14 carbonyl group of triptonide; iii) development of a new or improved synthesis to further satisfy the increasing demand of triptolide for the synthesis of clinical compounds such as LLDT-8 and minnelide.

\section{ORCID ${ }^{\circledR}$ iDs}

Hongtao Xu - https://orcid.org/0000-0001-5174-9079

\section{References}

1. Kupchan, S. M.; Court, W. A.; Dailey, R. G.; Gilmore, C. J.; Bryan, R. F. J. Am. Chem. Soc. 1972, 94, 7194-7195. doi:10.1021/ja00775a078

2. Liu, Q. Int. Immunopharmacol. 2011, 11, 377-383. doi:10.1016/j.intimp.2011.01.012

3. Ziaei, S.; Halaby, R. A. Avicenna J. Phytomed. 2016, 6, 149-164.

4. Park, B. Biochimie 2014, 105, 129-136. doi:10.1016/j.biochi.2014.07.003

5. Yue, Y.; Hikim, A. P. S.; Wang, C.; Leung, A.; Baravarian, S.; Reutrakul, V.; Sangsawan, R.; Chaichana, S.; Swerdloff, R. S. J. Androl. 1998, 19, 479-486.

6. Huang, J.; Zhou, L.; Wu, H.; Pavlos, N.; Chim, S. M.; Liu, Q.; Zhao, J.; Xue, W.; Tan, R. X.; Ye, J.; Xu, J.; Ang, E. S.; Feng, H.; Tickner, J.; Xu, J.; Ding, Y. Mol. Cell. Endocrinol. 2015, 399, 346-353. doi:10.1016/j.mce.2014.10.016

7. Qiu, D.; Kao, P. N. Drugs R\&D 2003, 4, 1-18. doi:10.2165/00126839-200304010-00001

8. Wei, Y.-m.; Wang, Y.-h.; Xue, H.-q.; Luan, Z.-h.; Liu, B.-w.; Ren, J.-h. Chin. J. Integr. Med. 2019, 25, 233-240. doi:10.1007/s11655-018-2847-z

9. Bao, X.; Cui, J.; Wu, Y.; Han, X.; Gao, C.; Hua, Z.; Shen, P. J. Mol. Med. (Heidelberg, Ger.) 2007, 85, No. 85. doi:10.1007/s00109-006-0113-x 
10. Zhao, F.; Chen, Y.; Li, R.; Liu, Y.; Wen, L.; Zhang, C. Toxicology 2010, 267, 70-79. doi:10.1016/j.tox.2009.10.023

11. Phillips, P. A.; Dudeja, V.; McCarroll, J. A.; Borja-Cacho, D.; Dawra, R. K.; Grizzle, W. E.; Vickers, S. M.; Saluja, A. K. Cancer Res. 2007, 67, 9407-9416. doi:10.1158/0008-5472.can-07-1077

12. Lin, J.; Chen, L.-Y.; Lin, Z.-X.; Zhao, M.-L. J. Int. Med. Res. 2007, 35, 637-643. doi:10.1177/147323000703500508

13. YinJun, L.; Jie, J.; YunGui, W. Leuk. Res. 2005, 29, 99-105. doi:10.1016/j.leukres.2004.05.014

14. Zhu, W.; Hu, H.; Quu, P.; Yan, G. Oncol. Rep. 2009, 22, 1397-1401. doi:10.3892/or_00000580

15. Carter, B. Z.; Mak, D. H.; Schober, W. D.; McQueen, T.; Harris, D.; Estrov, Z.; Evans, R. L.; Andreeff, M. Blood 2006, 108, 630-637. doi:10.1182/blood-2005-09-3898

16. Miyata, Y.; Sato, T.; Ito, A. Biochem. Biophys. Res. Commun. 2005, 336, 1081-1086. doi:10.1016/j.bbrc.2005.08.247

17. Tai, C.-J.; Wu, A. T. H.; Chiou, J.-F.; Jan, H.-J.; Wei, H.-J.; Hsu, C.-H.; Lin, C.-T.; Chiu, W.-T.; Wu, C.-W.; Lee, H.-M.; Deng, W.-P. BMC Cancer 2010, 10, 95. doi:10.1186/1471-2407-10-95

18. Hou, Z.-y.; Tong, X.-p.; Peng, Y.-b.; Zhang, B.-k.; Yan, M. Biomed. Pharmacother. 2018, 104, 771-780. doi:10.1016/j.biopha.2018.05.088

19. Liu, L.; Salnikov, A. V.; Bauer, N.; Aleksandrowicz, E.; Labsch, S.; Nwaeburu, C.; Mattern, J.; Gladkich, J.; Schemmer, P.; Werner, J.; Herr, I. Int. J. Cancer 2014, 134, 2489-2503. doi:10.1002/ijc.28583

20. Chen, Z.; Sangwan, V.; Banerjee, S.; Chugh, R.; Dudeja, V.; Vickers, S. M.; Saluja, A. K. Cancer Lett. 2014, 348, 156-166. doi:10.1016/j.canlet.2014.03.016

21.Zhou, G.-S.; Hu, Z.; Fang, H.-T.; Zhang, F.-X.; Pan, X.-F.; Chen, X.-Q.; Hu, A.-M.; Xu, L.; Zhou, G.-B. Leuk. Res. 2011, 35, 214-218. doi:10.1016/j.leukres.2010.07.013

22. Clawson, K. A.; Borja-Cacho, D.; Antonoff, M. B.; Saluja, A. K.; Vickers, S. M. J. Surg. Res. 2010, 163, 244-249. doi:10.1016/j.jss.2010.03.067

23. Carter, B. Z.; Mak, D. H.; Schober, W. D.; Dietrich, M. F.; Pinilla, C.; Vassilev, L. T.; Reed, J. C.; Andreeff, M. Blood 2008, 111, 3742-3750. doi:10.1182/blood-2007-05-091504

24. Raghavendra, N. M.; Pingili, D.; Kadasi, S.; Mettu, A.; Prasad, S. V. U. M. Eur. J. Med. Chem. 2018, 143, 1277-1300. doi:10.1016/j.ejmech.2017.10.021

25. Krakauer, T.; Chen, X.; Howard, O. M. Z.; Young, H. A. Immunopharmacol. Immunotoxicol. 2005, 27, 53-66. doi:10.1081/iph-51294

26. Liu, Q.; Chen, T.; Chen, G.; Li, N.; Wang, J.; Ma, P.; Cao, X. Biochem. Biophys. Res. Commun. 2006, 345, 1122-1130. doi:10.1016/j.bbrc.2006.05.024

27. Zhao, G.; Vaszar, L. T.; Qiu, D.; Shi, L.; Kao, P. N. Am. J. Physiol.: Lung Cell. Mol. Physiol. 2000, 279, L958-L966. doi:10.1152/ajplung.2000.279.5.1958

28. Zhou, H.-F.; Niu, D.-B.; Xue, B.; Li, F.-Q.; Liu, X.-Y.; He, Q.-H.; Wang, X.-H.; Wang, X.-M. NeuroReport 2003, 14, 1091-1095. doi:10.1097/01.wnr.0000073682.00308.47

29. Sun, M.; Song, H.; Ye, Y.; Yang, Q.; Xu, X.; Zhu, X.; Zhang, J.; Shi, S.; Wang, J.; Liu, Z. Biomed. Pharmacother. 2019, 109, 2375-2386. doi:10.1016/j.biopha.2018.11.081

30. Chen, D.; Ma, Y.; Wang, X.; Yu, S.; Li, L.; Dai, B.; Mao, Z.; Liu, H.; Liu, S.; Mei, C. A. J. Kidney Dis. 2014, 63, 1070-1072. doi:10.1053/j.ajkd.2014.01.418

31. Fan, D.; Guo, Q.; Shen, J.; Zheng, K.; Lu, C.; Zhang, G.; Lu, A.; He, X. Int. J. Mol. Sci. 2018, 19, 376. doi:10.3390/ijms 19020376
32. Yang, S.-X.; Gao, H.-L.; Xie, S.-S.; Zhang, W. R.; Long, Z.-Z. Int. J. Immunopharmacol. 1992, 14, 963-969. doi:10.1016/0192-0561(92)90139-c

33. Yang, F.; Ren, L.; Zhuo, L.; Ananda, S.; Liu, L. Exp. Toxicol. Pathol. 2012, 64, 905-911. doi:10.1016/j.etp.2011.03.013

34. Li, J.; Shen, F.; Guan, C.; Wang, W.; Sun, X.; Fu, X.; Huang, M.; Jin, J.; Huang, Z. PLoS One 2014, 9, e100685. doi:10.1371/journal.pone.0100685

35. Yang, F.; Wu, L.; Li, Y.; Wang, D. Drug Des., Dev. Ther. 2015, 9 , 6095-6107. doi:10.2147/dddt.s92022

36. Liu, J.; Jiang, Z.; Liu, L.; Zhang, Y.; Zhang, S.; Xiao, J.; Ma, M.; Zhang, L. Drug Chem. Toxicol. 2011, 34, 1-7. doi:10.3109/01480541003774358

37. Xu, L.; Qiu, Y.; Xu, H.; Ao, W.; Lam, W.; Yang, X. Food Chem. Toxicol. 2013, 57, 371-379. doi:10.1016/j.fct.2013.03.044

38. Chen, S.-W.; Zhou, N.-N.; Li, C. Mini-Rev. Org. Chem. 2012, 9 , 151-162. doi:10.2174/157019312800604661

39. Xu, H.; Liu, B. Eur. J. Med. Chem. 2019, 164, 342-351. doi:10.1016/j.ejmech.2018.12.058

40. Hou, W.; Liu, B.; Xu, H. Eur. J. Med. Chem. 2019, 176, 378-392. doi:10.1016/j.ejmech.2019.05.032

41. Yang, Y.-q.; Liang, J.; Han, X.-d.; Tian, R.-m.; Liu, X.-s.; Mao, W.; Xu, H.-t.; Liu, B.; Xu, P. Biomed. Pharmacother. 2019, 109, 1932-1939. doi:10.1016/j.biopha.2018.11.031

42. Yang, Y.-Q.; Yan, X.-T.; Wang, K.; Tian, R.-M.; Lu, Z.-Y.; Wu, L.-L.; Xu, H.-T.; Wu, Y.-S.; Liu, X.-S.; Mao, W.; Xu, P.; Liu, B. Front. Pharmacol. 2018, 9, No. 999. doi:10.3389/fphar.2018.00999

43. Xu, W.-D.; Li, L.-Q.; Li, M.-M.; Geng, H.-C.; Qin, H.-B. Nat. Prod. Bioprospect. 2016, 6, 183-186. doi:10.1007/s13659-016-0100-z

44. Lai, C. K.; Buckanin, R. S.; Chen, S. J.; Zimmerman, D. F.; Sher, F. T.; Berchtold, G. A. J. Org. Chem. 1982, 47, 2364-2369. doi:10.1021/jo00133a026

45. Sher, F. T.; Berchtold, G. A. J. Org. Chem. 1977, 42, 2569-2574. doi:10.1021/jo00435a008

46. Xu, H.; Tang, H.; Feng, H.; Li, Y. J. Org. Chem. 2014, 79, 10110-10122. doi:10.1021/j0501744j

47. Xu, H.; Tang, H.; Yang, Z.; Feng, H.; Li, Y. Tetrahedron 2014, 70, 3107-3115. doi:10.1016/j.tet.2014.03.070

48. Xu, H.; Tang, H.; Feng, H.; Li, Y. Tetrahedron Lett. 2014, 55, 7118-7120. doi:10.1016/j.tetlet.2014.11.010

49. Yang, D.; Wong, M.-K.; Cheung, K.-K.; Chan, E. W. C.; Xie, Y. Tetrahedron Lett. 1997, 38, 6865-6868. doi:10.1016/s0040-4039(97)01581-5

50. Zhang, H.; Li, H.; Xue, J.; Chen, R.; Li, Y.; Tang, Y.; Li, C. Org. Biomol. Chem. 2014, 12, 732-736. doi:10.1039/c3ob42183j

51. Cannillo, A.; Schwantje, T. R.; Bégin, M.; Barabé, F.; Barriault, L. Org. Lett. 2016, 18, 2592-2595. doi:10.1021/acs.orglett.6b00968

52. Zhou, Z.-L.; Yang, Y.-X.; Ding, J.; Li, Y.-C.; Miao, Z.-H. Nat. Prod. Rep. 2012, 29, 457. doi:10.1039/c2np00088a

53. Kaloun, E. B.; Long, C.; Molinier, N.; Brel, V.; Cantagrel, F.; Massiot, G. Tetrahedron Lett. 2016, 57, 1895-1898. doi:10.1016/j.tetlet.2016.03.060

54. Xu, H.; Tang, H.; Feng, H.; Li, Y. ChemMedChem 2014, 9, 290-295. doi:10.1002/cmdc.201300409

55. Xu, H.; Chen, Y.; Tang, H.; Feng, H.; Li, Y. Bioorg. Med. Chem. Lett. 2014, 24, 5671-5674. doi:10.1016/j.bmcl.2014.10.069

56. Xu, H.; Tang, H.; Feng, H.; Li, Y. Eur. J. Med. Chem. 2014, 73, 46-55. doi:10.1016/j.ejmech.2013.11.044 
57. Xu, H.; Fan, X.; Zhang, G.; Liu, X.; Li, Z.; Li, Y.; Jiang, B. Biomed. Pharmacother. 2017, 93, 1004-1009. doi:10.1016/j.biopha.2017.06.041

58. Xu, H.; Liu, L.; Fan, X.; Zhang, G.; Li, Y.; Jiang, B. Bioorg. Med. Chem. Lett. 2017, 27, 505-510. doi:10.1016/j.bmcl.2016.12.032

59. Aoyagi, Y.; Hitotsuyanagi, Y.; Hasuda, T.; Matsuyama, S.; Fukaya, H.; Takeya, K.; Aiyama, R.; Matsuzaki, T.; Hashimoto, S. Bioorg. Med. Chem. Lett. 2008, 18, 2459-2463. doi:10.1016/j.bmcl.2008.02.039

60. Aoyagi, Y.; Hitotsuyanagi, Y.; Hasuda, T.; Fukaya, H.; Takeya, K.; Aiyama, R.; Matsuzaki, T.; Hashimoto, S. Bioorg. Med. Chem. 2006, 16, 1947-1949. doi:10.1016/j.bmcl.2005.12.098

61. Patil, S.; Lis, L. G.; Schumacher, R. J.; Norris, B. J.; Morgan, M. L.; Cuellar, R. A. D.; Blazar, B. R.; Suryanarayanan, R.; Gurvich, V. J.; Georg, G. I. J. Med. Chem. 2015, 58, 9334-9344. doi:10.1021/acs.jmedchem.5b01329

62.Zhou, R.; Zhang, F.; He, P.-L.; Zhou, W.-L.; Wu, Q.-L.; Xu, J.-Y.; Zhou, Y.; Tang, W.; Li, X.-Y.; Yang, Y.-F.; Li, Y.-C.; Zuo, J.-P. Int. Immunopharmacol. 2005, 5, 1895-1903. doi:10.1016/j.intimp.2005.06.009

63. Frieze, D. M.; Berchtold, G. A.; Blount, J. F. Tetrahedron Lett. 1978, 19, 4607-4610. doi:10.1016/s0040-4039(01)85683-5

64. Tahara, A.; Akita, H. Chem. Pharm. Bull. 1975, 23, 1976-1983. doi:10.1248/cpb.23.1976

65. Koike, H.; Tokoroyama, T. Tetrahedron Lett. 1978, 19, 4531-4534. doi:10.1016/s0040-4039(01)95270-0

66. Buckanin, R. S.; Chen, S. J.; Frieze, D. M.; Sher, F. T.; Berchtold, G. A. J. Am. Chem. Soc. 1980, 102, 1200-1201. doi:10.1021/ja00523a065

67. Van Tamelen, E. E.; Demers, J. P.; Taylor, E. G.; Koller, K. J. Am. Chem. Soc. 1980, 102, 5424-5425. doi:10.1021/ja00536a065

68. Alvarez-Manzaneda, E.; Chahboun, R.; Bentaleb, F.; Alvarez, E.; Escobar, M. A.; Sad-Diki, S.; Cano, M. J.; Messouri, I. Tetrahedron 2007, 63, 11204-11212. doi:10.1016/j.tet.2007.07.088

69. Zhou, B.; Li, X.; Feng, H.; Li, Y. Tetrahedron 2010, 66, 5396-5401. doi:10.1016/j.tet.2010.05.035

70. Garver, L. C.; Van Tamelen, E. E. J. Am. Chem. Soc. 1982, 104, 867-869. doi:10.1021/ja00367a046

71. Miller, N. A.; Willis, A. C.; Sherburn, M. S. Chem. Commun. 2008, 1226. doi:10.1039/b718754h

72. Barrett, A.; Ma, T.-K.; Mies, T. Synthesis 2019, 51, 67-82. doi:10.1055/s-0037-1610382

73. Van Tamelen, E. E.; Leiden, T. M. J. Am. Chem. Soc. 1982, 104, 1785-1786. doi:10.1021/ja00370a077

74. Yang, D.; Ye, X.-Y.; Gu, S.; Xu, M. J. Am. Chem. Soc. 1999, 121, 5579-5580. doi:10.1021/ja9901664

75. Yang, D.; Ye, X.-Y.; Xu, M. J. Org. Chem. 2000, 65, 2208-2217. doi:10.1021/jo9919613

76. Yang, D.; Ye, X.-Y.; Xu, M.; Pang, K.-W.; Zou, N.; Letcher, R. M. J. Org. Chem. 1998, 63, 6446-6447. doi:10.1021/jo981362g

77. Yang, D.; Xu, M.; Bian, M.-Y. Org. Lett. 2001, 3, 111-114. doi:10.1021/ol0068243

78. Goncalves, S.; Santoro, S.; Nicolas, M.; Wagner, A.; Maillos, P.; Himo, F.; Baati, R. J. Org. Chem. 2011, 76, 3274-3285. doi:10.1021/jo2001116

\section{License and Terms}

This is an Open Access article under the terms of the Creative Commons Attribution License (http://creativecommons.org/licenses/by/4.0). Please note that the reuse, redistribution and reproduction in particular requires that the authors and source are credited.

The license is subject to the Beilstein Journal of Organic Chemistry terms and conditions: (https://www.beilstein-journals.org/bjoc)

The definitive version of this article is the electronic one which can be found at:

doi:10.3762/bjoc. 15.194 